\title{
Phenolic compounds from the rhizome of Renealmia nicolaioides Loes.: a new diarylheptanoid
}

\author{
KATHLYN V. GEVÚ ${ }^{1}$, MÁRIO G. DE CARVALHO ${ }^{2}$, ILNA G. DA SILVA ${ }^{2}$, HELENA \\ R.P. LIMA ${ }^{3}$, ROSANE N. CASTRO ${ }^{2}$ and MAURA DA CUNHA ${ }^{1}$
}
${ }^{1}$ Centro de Biociências e Biotecnologia, Universidade Estadual do Norte Fluminense Darcy Ribeiro, Av. Alberto Lamego, 2000, Parque Califórnia, 28013-602 Campos dos Goytacazes, RJ, Brazil
${ }^{2}$ Instituto de Ciências Exatas, Departamento de Química, Universidade Federal Rural do Rio de Janeiro, BR 465, Km 07, s/n, 23897-000 Seropédica, RJ, Brazil
${ }^{3}$ Instituto de Ciências Biológicas e da Saúde, Departamento de Botânica, Universidade Federal Rural do Rio de Janeiro, BR 465, Km 07, s/n, 23897-000 Seropédica, RJ, Brazil

Manuscript received on March 28, 2018; accepted for publication on August 13, 2018

\begin{abstract}
How to cite: GEVÚ KV, CARVALHO MG, SILVA IG, LIMA HRP, CASTRO RN AND DA CUNHA M. 2019. Phenolic compounds from the rhizome of Renealmia nicolaioides Loes.: a new diarylheptanoid. An Acad Bras Cienc 91: e20180312. DOI 10.1590/0001-3765201920180312.

Abstract: This study aims to identify phenolic compounds in dichloromethane and methanolic extracts of the rhizome of Renealmia nicolaioides collected in the North Region of Brazil. Two known diarylheptanoids, 1,7-bis(4-hydroxyphenyl)-(1E)-1-hepten-3-one (1), and 5R-1,7-bis(4-hydroxyphenyl)1E-hepten-5-ol (2), and a new one (1R,2S,5S)-2-hydroxy-1,7(p-hydroxyphenyl)-centrolobine (3), as well as one flavonoid, 3-metoxi-quercetin (4) were isolated by chromatographic procedure and identified by spectroscopic techniques (1H and13C NMR, HRMS and CD). The acetyl derivative of 2 was used to confirm its structure. All four compounds are reported for the first time for this genus, and this is the first occurrence of compound 1 as a natural metabolite. The results reported here are unprecedented for the genus Renealmia.
\end{abstract}

Key words: Flavonoid, Alpinieae tribe, Zingiberaceae, underground organ.

\section{INTRODUCTION}

The genus Renealmia L.f. belongs to the family Zingiberaceae, subfamily Alpinioideae, and tribe Alpinieae, and contains approximately 75 species distributed throughout tropical regions of the Americas and Africa (Maas 1977). In Brazil, the genus is represented by 21 species distributed throughout several regions and phytogeographical domains of the country including Amazonia,

Correspondence to: Maura da Cunha

E-mail: maurauenf@gmail.com

ORCid: http://orcid.org/0000-0003-1078-3742
Caatinga, Cerrado, Atlantic Forest, Pampa, and the Pantanal (Maas and Maas 2015). Some species of Renealmia are used for medicinal purposes, with anticancer activity and snakebite treatment being the most notable (Negrelle 2015).

Phytochemical investigations have been conducted with species of Renealmia and have revealed the presence of terpenes, flavonoids and diarylheptanoids (Luz et al. 1984, Ramiandrasoa et al. 1986, Lognay et al. 1991, Zhou et al. 1997, Yang et al. 1999, Kaplan et al. 2000, Sekiguchi et al. 2001, 2002, Gu et al. 2002, Maia et al. 2007, 
Cabanillas et al. 2014, Gilli et al. 2014, GómezBetancur et al. 2014, 2015, Noriega et al. 2016).

Flavonoids isolated from roots of $R$. nicolaioides induced quinone reductase enzyme phase II, which acts in the protective mechanism against tumor action in hepatocytes ( $\mathrm{Gu}$ et al. 2002). Flavonoids and diarylheptanoids isolated from the ethanolic extract of $R$. thyrsoidea rhizome acted against the amastigote form of Leishmania amazonensis (Cabanillas et al. 2014). Pinostronbin, a flavanone isolated from leaves of $R$. alpinia, inhibited enzymatic and biological activities of PLA2, which is the most abundant and important constituent of snake venoms (Gómez-Betancur et al. 2016).

Most diarylheptanoids are phenols whose anticancer activity has been widely investigated (Wei et al. 2005, Dong et al. 2015, Agrawal et al. 2010, Cabanillas et al. 2014, Gilli et al. 2014).

Among the compounds isolated from Renealmia spp., phenols stand out. Thus, this work aims to identify the phenolic compounds present in the rhizome of $R$. nicolaioides.

\section{MATERIALS AND METHODS}

\section{PLANT MATERIAL}

Rhizomes of $R$. nicolaioides were collected in June 2015, at the Catuaba Experimental Farm and the Humaitá Forest Reserve, both located in Rio Branco, state of Acre. The material was identified and a voucher (No. 6646) was deposited in the herbarium of the Universidade Federal do Acre (UFACPZ).

\section{EQUIPMENT}

One- and two-dimensional ${ }^{1} \mathrm{H}$ and ${ }^{13} \mathrm{C}$ nuclear magnetic resonance (NMR) spectra were obtained using a Bruker NMR spectrometer [400 and $500 \mathrm{MHz}\left({ }^{1} \mathrm{H}\right), 100$ and $\left.125 \mathrm{MHz}\left({ }^{13} \mathrm{C}\right)\right]$, using tetramethylsilane (TMS) as internal standard for chemical shift reference. High-resolution electrospray ionization mass spectrometry (EIHRMS) using a quadrupole-time-of-flight mass spectrometer (XEVO-QToF) was used to obtain the mass spectra. High-performance liquid chromatography (HPLC) measurements were performed using an instrument equipped with a LC-10AS pump, a SPD-10A detector, a CBM20A-Comunications Module (Shimadzu), and a Rheodyne injector with loop of $500 \mu \mathrm{L}$. Optical rotation was performed using a JASCO PTC 203 digital polarimeter and a JASCO J-815 CD spectrometer.

\section{EXTRACTION AND ISOLATION}

Air-dried powdered rhizomes (155 g) were successively extracted with $\mathrm{CH}_{2} \mathrm{Cl}_{2}$ and $\mathrm{CH}_{3} \mathrm{OH}$ at room temperature. Three extractions were made with dichloromethane, while the extraction with the methanol was exhaustive. The periodicity of solvent exchange was on average 48 hours, and each solution was concentrated on a rotary evaporator under vacuum. This process yielded two extracts: dichloromethane rhizome (RNRD) and methanol rhizome (RNRM).

The RNRD extract (1.05 g) was subjected to silica gel column chromatography (CC) eluted with solvents of increasing polarity [n-hexane:dichlorometane $(1: 1$ to $2: 8)$ and chloroform:methanol (1:0 to 9:2)] to give 20 fractions. Fraction $12(0.14 \mathrm{~g})$ was subjected to silica gel column chromatography (CC) eluted with solvents of increasing polarity [dichloromethane:ethyl acetate (1:0 to $0: 1)$ and methanol] to give eight subfractions. Compound 1 was purified and identified in subfraction 3 (13 $\mathrm{mg})$. Fraction 17 (80 mg) was subjected to column chromatography using Sephadex LH-20 eluted with methanol to give subfractions. The subfraction 17.2 (18 mg) was subjected to fractionation by HPLC. The chromatographic conditions were water:acetic acid (99:1) as solvent (A) and acetronitrile as solvent 
(B) in a ratio of $4: 6$. The mobile phase was filtered before use and delivered isocratically at a flow rate of $1 \mathrm{ml} \mathrm{min}$. The analysis was conducted at room temperature using a Betasil C18 semi-preparative column (25 mm x $4.6 \mathrm{~mm}$ i.d., $5 \mu \mathrm{m}$ ), and the analyses were monitored at $270 \mathrm{~nm}$. In addition to some unidentified components, diarylheptanoid, represented by peak at $5.094 \mathrm{~min}$, was isolated and identified as compound $\mathbf{3}$.

The RNRM extract (10 g) was solubilized in methanol:water (3:1) and subjected to liquid-liquid partitioning by organic solvents of increasing polarity [hexano (RNRM-H), dichloromethane (RNRM-D), ethyl acetate (RNRM-Ac), butanol (RNRM-B), and water (RNRM- $\left.\mathrm{H}_{2} \mathrm{O}\right)$ ]. Threecolumn chromatography (CC) was performed with the dichloromethane fraction.

First, RNRM-D (2 g) was subjected to silica gel column chromatography (CC) eluted with dichlorometane:methanol $(1: 0$ to $0: 1)$ to give 8 fractions. The subfractions $2(38 \mathrm{mg})$ and $3(55$ $\mathrm{mg}$ ) were subjected to column chromatography using Sephadex LH-20 eluted with methanol to give four and six subfractions, respectively. Subfraction $2.4(86 \mathrm{mg})$ was subjected to preparative plate chromatography and eluted with chloroform:methanol (9:1) to give two subfractions (2.4.1 and 2.4.2). Compounds 1 and $\mathbf{2}$ were purified and identified in subfraction 2.4.1 (7 mg) and 2.4.2 (5 mg), respectively. Subfraction 3.1 (48 mg) was subjected to preparative plate chromatography and eluted with chloroform:methanol (9:1) to give two subfractions (3.1.1 and 3.1.2). Compounds 2 and 1 were again purified and identified in subfraction $3.4 .1(21 \mathrm{mg})$ and $3.4 .2(20 \mathrm{mg})$, respectively. Fraction $4(98 \mathrm{mg})$ was subjected to silica gel column chromatography (CC) eluted with methanol to give three subfractions. The compound $\mathbf{2}$ was again purified and identified in subfraction 4.1 (36 mg).

Second, RNRM-D (1.7 g) was subjected to a silica gel column chromatography (CC) eluted with chloroform:ethyl acetate $(9: 1$ to $0: 1)$ and ethyl acetate:methanol (98:2 to 0:1) to give 13 fractions. Compound $\mathbf{1}$ was again purified and identified in fraction 5. Fraction $8(0.13 \mathrm{~g})$ was rechromatographed over Sephadex LH-20 eluted with $\mathrm{MeOH}$ to give four subfractions. Subfraction 8.2 (0.2 g) was rechromatographed over Sephadex LH-20 eluted with methanol to give four subfractions. Compound $\mathbf{2}$ was again purified and identified in subfraction 8.2.3 (0.12 g).

Third, RNRM-D (0.6 g) was subjected to column chromatography using Sephadex LH-20 eluted with methanol:dichlorometane (8:2). Compound 4 was purified and identified in fraction $4(6 \mathrm{mg})$.

Derivative 2a. 5R-1,7-bis( $p$-acetoxyphenyl)(1E)-1-hepten-5-acetate. This derivative was obtained as described by Bandeira et al. (2007). ${ }^{1} \mathrm{H}$ and ${ }^{13} \mathrm{C}$ NMR data of $2 \mathbf{a}(400 / 100 \mathrm{MHz}$, Methanol-d $\left.{ }_{4}\right): 7.38$ (d, 8.2 Hz, H-2',6'), 7.02 (d, $8.2 \mathrm{~Hz}, \mathrm{H}-3$ ',5'), 7.23 (d, 8.2 Hz, H-2",6”), 6.97 (d, 8.2 Hz, H-3", 5"), 6.38 (d, 16.0 Hz, H-1), 6.23 (dt, 16.0 and $7.2 \mathrm{~Hz}, \mathrm{H}-2$ ), 4.98 (qui, $6.8 \mathrm{~Hz}, \mathrm{H}-5$ ), 2.73 and 2.62 (m, H-7), 2.24 (m. H-3), 1.93 (m, H-6), $1.77(\mathrm{~m}, \mathrm{H}-4) ; 2.02\left(\mathrm{~s}, 3 \mathrm{H}, \mathrm{O}_{2} \mathrm{CCH}_{3}\right)$, and 2.26(s, $3 \mathrm{H})$ and $2.28(\mathrm{~s}, 3 \mathrm{H})$ of $2 \mathrm{xO}_{2} \mathrm{CCH}_{3} . \delta_{\mathrm{C}}: 171.5$, $169.9,169.8\left(3 \times \mathrm{O}-\mathrm{CO}-\mathrm{CH}_{3}\right), 149.7,149.0(\mathrm{C}-$ 4",4"), 139.1 (C-1'”), 135.1(C-1"), 128.9 (C-2',6'), 126.4 (C-2",6"), 121.3 and 121.2 (C-3',5' e 3",5"), 73.2(C-5), 35.5 C-6), 33.4 (C-4), 30.7 (C-7), 28.6 (C-3). 19.7, 19.5, 19.5 (3x O $\left.\mathrm{C}_{2}-\mathrm{CH}_{3}\right) \cdot[\alpha]_{\mathrm{D}}+11.771$.

1R,2S,5S-2-hydroxy-1,7(p-hydroxyphenyl)centrolobine (3). MP: $160-162^{\circ} \mathrm{C}$. UV: $\lambda_{\text {max }} \mathrm{MeOH}$, nm (log $\varepsilon$ ): 285 (0.3), 225 (1.6), 202(1.5), CD (c $\left.196.25 \times 10^{-4} \mathrm{mg} / \mathrm{mL}, \mathrm{MeOH}\right): \lambda_{\max } \mathrm{nm}(\theta \mathrm{mdeg})$ : 275 (0), $225(+15), 202(+16), 200(0) ;{ }^{1} \mathrm{H}$ and ${ }^{13} \mathrm{C}$ NMR data see Table I. ESI-HRMS: $m / z(\%)$ : positive mode: 315.1599 [M+H, (25)], calc 315.1596, 297.1500 (40), 279.1397 (20), 147.0788 (20), 133.1063 (100), and negative mode: 313.1447[MH, (100), calc. 313.1439, 205.0852 (30). 


\section{RESULTS AND DISCUSSION}

Three diarylheptanoids were identified, including two known compounds $(\mathbf{1}, \mathbf{2})$ and one new one $(3)$, by analysis of $1 \mathrm{D}$ and 2D NMR spectra (Figure 1). Compound 1 was identified by two pairs of doublets $\left(8.0 \mathrm{~Hz}, 2 \mathrm{H}\right.$ each) at $\delta_{\mathrm{H}} 7.50 / 6.82$, and $7.0 / 6.69$ of two p-substituted aromatic rings, two doublets $(15 \mathrm{~Hz}, 1 \mathrm{H}$ each $)$ at $\delta_{\mathrm{H}} 7.56 / 6.65$ of a transenone, two triplets $\left(7.5 \mathrm{~Hz}, 2 \mathrm{H}\right.$ each) at $\delta_{\mathrm{H}} 2.71$ and 2.57 , and a multiplet at $1.86(4 \mathrm{H})$. Analysis of the HMQC spectrum allowed the identification of signals of ${ }^{1} \mathrm{~J}_{\mathrm{HC}}$ of these respective detected protons with carbons at $\delta_{\mathrm{CH}} 130.2 / 115\left(\mathrm{CH}-2^{\prime}, 6^{\prime} / 3^{\prime} .5^{\prime}\right)$, 128.9/114.6 (CH-2",6"/3",5"), confirming the two AA'BB' systems, and 143.8/122.3 (CH-1/2) of enone), and $\delta_{\mathrm{CH} 2} 39.7,34.4,31.1$ and 23.9 of $\mathrm{CH} 2-4,7,5$ and 6, respectively. The signals of $\delta_{\mathrm{C}}$ at $202.2,160.7,154.9,132.9$, and 125.6 confirmed the two aromatic rings and the enone in the proposed structure of the diarylheptanoid. These data were compared with those of the synthetic product registered in the literature (Jirásek et al. 2014) and was identified as E-1,7-bis(4-hydroxyphenyl)-hept1-en-3-one (1), identified for the first time as natural product. The same analysis was performed for $\mathbf{2}$. In addition to two AA'BB of aromatic systems $\left[\delta_{\mathrm{H}} /\right.$ $\delta_{\mathrm{C}}:$ 7.15/126.8(CH-2",6"), 6.72/114.5(CH-3",5"); 7.0/128.8 (CH-2',6'), 6.7/114.6 (CH-3',5'), a trans double bond $\left[\delta_{\mathrm{H}} / \delta_{\mathrm{C}}: 6.30(\mathrm{~d}, 16 \mathrm{~Hz}) / 129.6(\mathrm{CH}-\right.$ 1), $6.0\left(\mathrm{dt}, J_{1} 16.0\right.$ and $\left.\left.J_{2} 6.8 \mathrm{~Hz}\right) / 127.0(\mathrm{CH}-2)\right]$, and one $\mathrm{CH}[3.59$ (qui, $7.5 \mathrm{~Hz}$ )/70.0(CH)] which ${ }^{2,3} \mathrm{~J}_{\mathrm{HC}}$ (HMBC) located at C-5, were confirmed. The heptanoid was completed by for methylene groups with $\left[\delta_{\mathrm{H}} / \delta_{\mathrm{C}}: 2.25\right.$ and $2.30(\mathrm{~m}) / 28.8\left(\mathrm{CH}_{2}-3\right)$, $1.6(\mathrm{~m}) / 36.9\left(\mathrm{CH}_{2}-4\right), 1.70(\mathrm{~m}) / 39.2\left(\mathrm{CH}_{2}-6\right), 2.55$ and $\left.2.70(\mathrm{~m}) / 30.7\left(\mathrm{CH}_{2}-7\right)\right]$. Additional analysis of DEPTQ and HMBC spectra was used to confirm the chemical shift of quaternary carbons of $\mathbf{2}$. The new triacetyl derivative (2a) was prepared to confirm its structure (see Materials and Methods). These data of the natural diarylheptanoid, including the $[\alpha]_{D}$ $+20.325,\left[\right.$ Lit $\left.[\alpha]_{\mathrm{D}}+3.5\left([\alpha]_{\mathrm{D}} 0.1, \mathrm{MeOH}\right)\right]$, were similar to those of 5R-1,7-bis(5-hydroxyphenyl)(1E)-1-hepten-5-ol, isolated from the rhizomes of Curcuma kwangsiensis (Li et al. 2010), defining this structure for 2 (Figure 1).

The analysis of ${ }^{1} \mathrm{H}$ and ${ }^{13} \mathrm{C}$ spectra of compound 3 allowed the identification of two aromatic systems similar to compounds $\mathbf{1}$ and 2. These spectra, including the $2 \mathrm{D}$ experiments $\left({ }^{1} \mathrm{Hx}^{1} \mathrm{H}-\mathrm{COSY}, \mathrm{HMQC}\right.$ and HMBC), showed signals for four methylene groups, and three methyne oxygenated carbons (Table I). The values of $\mathrm{m} / \mathrm{z}$ detected by HRMS in negative mode, $\mathrm{m} / \mathrm{z}$ 313.1442 , and in positive mode, $\mathrm{m} / \mathrm{z} 315.1599$, were used to confirm the proposed structure as $\mathbf{3}$ (Figure 1). The $\delta_{\mathrm{C}}$ and $\delta_{\mathrm{H}}$ detected in the HMQC spectrum, the multiplicity allied to $\mathrm{J}_{\mathrm{H}, \mathrm{H}}$ values, as well as analyses of ${ }^{1} \mathrm{Hx}{ }^{1} \mathrm{H}-\mathrm{COSY}$ and $\mathrm{HMBC}$ spectra in methanol and in $\mathrm{CDCl}_{3}$, such as the ${ }^{3} \mathrm{~J}_{\mathrm{HC}}$ of $\mathrm{H}-7 / \mathrm{C}-5, \mathrm{H}-1 / \mathrm{C}-2$, and $\mathrm{H}-1 / \mathrm{H}-5$ (Table I), lead to the proposal of a pyran ring as shown in 3 (Figure 1). The relative stereochemistry was based on the NOE signals observed in the NOESY experiments, such as $\mathrm{H}-1 / \mathrm{H}-3, \mathrm{H}-1 / \mathrm{H}-5$, and by $\mathrm{J}_{\mathrm{H}, \mathrm{H}}$ value $(9.0 \mathrm{~Hz})$ of $\mathrm{H}-1 \mathrm{ax} / \mathrm{H}-2 \mathrm{ax}$. Positive EC observed in the dichroism circular spectrum $(\Theta$ : 15 mdeg, $\lambda_{\max } 225 \mathrm{~nm}$, methanol), is compatible with an R configuration of oxybenzyl carbon, such as the observed positive EC for C-2 (oxybenzyl) of flavonoid (Slade et al. 2005). These data, allied with relative stereochemistry, allowed the definition of the absolute stereochemistry of this new compound (3) as 1R,2S,5S-2-hydroxy-1,7(p-hydroxyphenyl)centrolobine (3) (Figure 1).

Compound 4 was identified as flavonoid by ${ }^{1} \mathrm{H}$, ${ }^{13} \mathrm{C}\left(\mathrm{MeOH}_{4}, 500 / 125 \mathrm{MHz}\right) 1 \mathrm{D}$ and 2D spectral analyses and comparison with literature data. Signals at $\delta_{\mathrm{H}} 6.2(\mathrm{bs}), 6.4(\mathrm{bs}), 6.91(\mathrm{~d}, 8.0 \mathrm{~Hz}), 7.53(\mathrm{bd}, 8.0$ $\mathrm{Hz})$ and $7.63(\mathrm{bs})$ of protons linked to carbons at $\delta_{\mathrm{CH}}$ 99.8, 94.7, 116.0, 116.4, 122.3 of $\mathrm{CH} \mathrm{6,} \mathrm{8,} \mathrm{5',} \mathrm{6'} \mathrm{and}$ 2 ', respectively. An additional singlet at $\delta_{\mathrm{CH} 3} 3.79$ of $3 \mathrm{H}$ with ${ }^{1} \mathrm{~J}_{\mathrm{HC}}$ and ${ }^{3} \mathrm{~J}_{\mathrm{HC}}$ with carbons at $\delta_{\mathrm{CH} 3} 59.1$ 


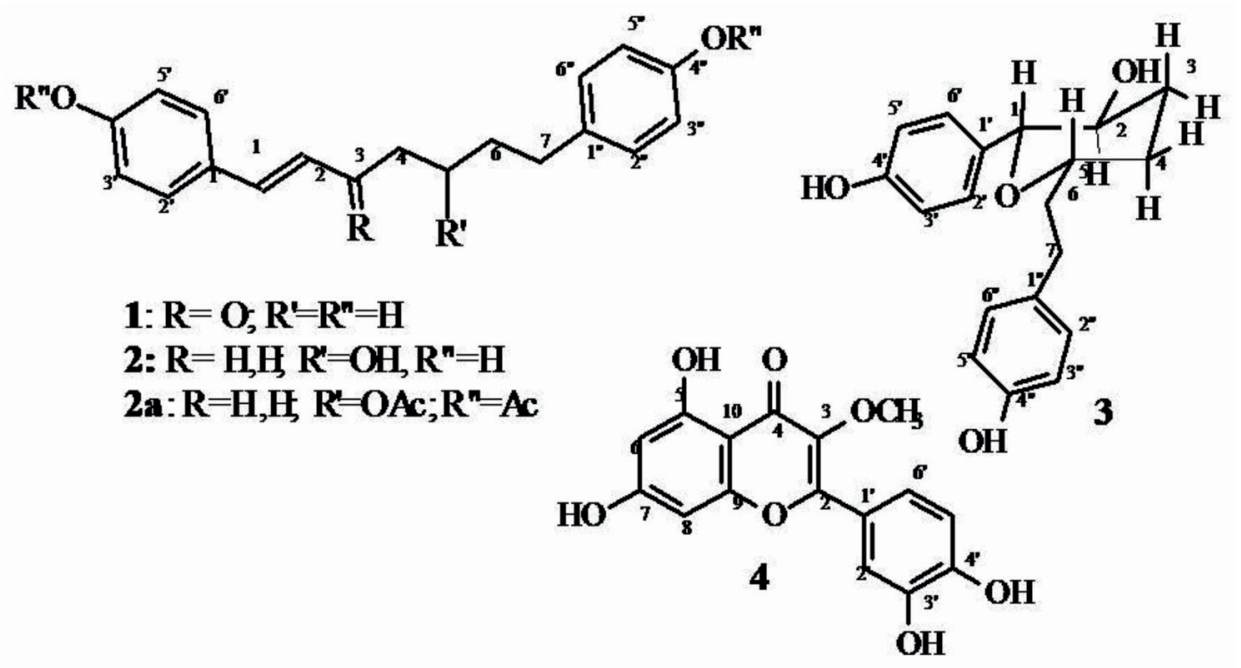

Figure 1 - Structures of compounds isolated from rhizomes of $R$. nicolaioides.

and $\delta_{\mathrm{C}} 138.0$, respectively, allowed the inclusion of a methyl group at C-3 in the flavonoid structure. The additional signals of $\delta_{\mathrm{C}}$ detected in the DEPTQ NMR spectrum, and the value of $\mathrm{m} / \mathrm{z} 316\left(\mathrm{M}^{+}\right)$observed in the mass spectrum, were compatible with the quercetin 3-methyl ether. These data are similar to those of the flavonoid registered in the literature (Rashed et al. 2014).

Compound 1, which is abisdemethoxycurcumin derivate, is being described for the first time from a natural source, although it had been previously synthesized (Jirásek et al. 2014).

Diarylheptanoid 2 has been detected in rhizomes of Curcuma species (Zingiberaceae) C. comosa Roxb., C. elata Roxb. and C. kwangsiensis S.K. Lee $\&$ C.F. Liang. This compound has been shown to exhibit antiallergic activity, potent cytotoxic activity against both the KB and NCI-H187 cell lines, and inhibitory activity for melanogenesis, and may be used in the treatment of skin diseases (Li et al. 2010, Matsumoto et al. 2013, 2015, Chokchaisiri et al. 2014).

Flavonoid 4 was isolated from the rhizome of $R$. nicolaioides. Other flavonoids have also been isolated from the roots of $R$. nicolaioides ( $\mathrm{Gu}$ et al. 2002), the leaves of $R$. thyrsoidea, $R$. cernua and R. alpinia (Cabanillas et al. 2014, Gilli et al. 2014,
Gómez-Betancur et al. 2014, 2015), and from the rhizome of $R$. thyrsoidea (Cabanillas et al. 2014). Flavonoids are used as chemosystematic markers for the Zingiberaceae (Lima and Kaplan 2010), and are commonly found among its genera.

The occurrence of the diarylheptanoids $\mathbf{1}$ and 2 in four different fractions from the rhizome of $R$. nicolaioides could be potential chemotaxonomic markers for this species. Further phytochemical studies with other species of Renealmia are needed to fully understand the chemosystematic significance of these compounds for this genus. Compound $\mathbf{3}$ can be considered as a biosynthetic precursor of 2.

The high diversity of metabolites found in the Amazonian Renealmia nicolaioides strongly recommends further investigation into the chemical and biological properties of the species.

\section{ACKNOWLEDGMENTS}

The first author would like to thank the Coordenação de Aperfeiçoamento de Pessoal de Nível Superior (CAPES) for granting a scholarship. The authors would like to thank the Conselho Nacional de Desenvolvimento Científico e Tecnológico (CNPq) and the Fundação Carlos Chagas Filho de Amparo 
TABLE I

${ }^{1} \mathrm{H}$ and ${ }^{13} \mathrm{C}$ NMR data of diarylheptanoid 3 in $\mathrm{D}_{3} \mathrm{COD}(500 \mathrm{MHz})$ and $\mathrm{CDCl}_{3}(600 \mathrm{MHz})$.

\begin{tabular}{|c|c|c|c|c|c|c|}
\hline $\mathbf{C}$ & $\boldsymbol{\delta}_{\mathrm{H}}$ & $\boldsymbol{\delta}_{\mathrm{C}}$ & $\boldsymbol{\delta}_{\mathrm{H}}$ & $\boldsymbol{\delta}_{\mathrm{C}}$ & ${ }^{2,3} \mathbf{J}_{\mathrm{HC}^{*}}$ & NOE* \\
\hline & \multicolumn{2}{|l|}{$\mathrm{D}_{3} \mathrm{CO}-\mathrm{D}$} & \multicolumn{2}{|l|}{$\mathrm{CDCl}_{3}$} & & \\
\hline 1 & $3.98(\mathrm{~d}, 9 \mathrm{~Hz})$ & 84.3 & $3.98(\mathrm{~d}, 9.0 \mathrm{~Hz})$ & 86.3 & $\begin{array}{c}\text { C-1', } 2 ; 3 ; \\
5 ; 2^{\prime}, 6\end{array}$ & H-2',6'; 5;3 \\
\hline 2 & $3.48(\mathrm{~m})$ & 70.0 & $3.5(\mathrm{td}, 9.0,9.0,4.2 \mathrm{~Hz}$ & 71.9 & & 2'.6'; 3eq; 4ax; \\
\hline 3 & $2.1(\mathrm{~m}) ; 1.55(\mathrm{~m})$ & 33.9 & $2.12(\mathrm{dbr}, 12 \mathrm{~Hz}) ; 1.55(\mathrm{~m})$ & 34.3 & & $\mathrm{H}-1 ; 4$ \\
\hline 4 & $1.50(\mathrm{~m}), 1.75(\mathrm{~m})$ & 31.4 & $1.77(\mathrm{~m}) ; 1.49(\mathrm{~m})$ & 32.5 & & $\mathrm{H}-7$ \\
\hline 5 & $3.48(\mathrm{~m})$ & 76.6 & $3.40(\mathrm{~m})$ & 78.4 & & $\mathrm{H}-6 ; 7$ \\
\hline 6 & $1.66 ; 1.74(\mathrm{~m})$ & 38.1 & $1.75(\mathrm{~m}), 1.60(\mathrm{~m})$ & 39.0 & $\mathrm{C}-1 " ; 5 ; 7$ & H-2",6"; 7 \\
\hline 7 & $2.7 \mathrm{~m} \mathrm{(2H)}$ & 31.0 & $2.57(\mathrm{~m})$ & 32.0 & $\begin{array}{c}\text { C-1"; } \\
\text { 2",6";6;5 }\end{array}$ & H-2",6"; 4; 1 \\
\hline 1 ' & - & 132.3 & - & 132.9 & & - \\
\hline $2^{\prime}, 6^{\prime}$ & $7.34(\mathrm{~d}, 8 \mathrm{~Hz})$ & 129.4 & 7.12(d, $9.0 \mathrm{~Hz})$ & 130.3 & C-1;4'; & $\mathrm{H}-1 ; 5$ \\
\hline $3^{\prime}, 5^{\prime}$ & $6.84(\mathrm{~d}, 8 \mathrm{~Hz})$ & 114.9 & $6.77(\mathrm{~d}, 9.0 \mathrm{~Hz})$ & 116.0 & C-4';2',6';1' & \\
\hline $4^{\prime}$ & - & 157.0 & - & 158.4 & & \\
\hline $1 "$ & - & 132.7 & - & 134.5 & & \\
\hline $2 ", 6 "$ & $7.15(\mathrm{~d}, 8 \mathrm{~Hz})$ & 129.6 & $6.97(9.0 \mathrm{~Hz})$ & 130.4 & C-7;4”;1” & Н-7; 6;4 \\
\hline $3 ”, 5 ”$ & $6.80(\mathrm{~d}, 8 \mathrm{~Hz})$ & 115.3 & $6.66(9.0)$ & 116.0 & C-4”;1” & \\
\hline 4" & - & 155.7 & - & 156.3 & & \\
\hline
\end{tabular}

*From the observed signs with two solvents.

à Pesquisa do Estado do Rio de Janeiro (FAPERJ) for their financial support, and Herison Medeiros and staff of Herbarium of the Universidade Federal do Acre (UFACPZ) for logistical and technical support. This study was part of the $\mathrm{PhD}$ of the first author in the Programa de Pós-Graduação em Biociências e Biotecnologia of the Universidade Estadual do Norte Fluminense Darcy Ribeiro (UENF).

\section{AUTHOR CONTRIBUTIONS}

KVG and HRPL participated in sample collection and identified the species. KVG, MGC, IGS and RNC performed the chemical analyzes. KVG, MGC, HRPL and MDC analyzed the data and wrote the paper.

\section{REFERENCES}

AGRAWAL DK AND MISHRA PK. 2010. Curcumin and its analogues: potential anticancer agents. Med Res Rev 30: 818-860.
CABANILLAS BJ ET AL. 2014. Leishmanicidal compounds and potent PPAR $\gamma$ activators from Renealmia thyrsoidea (Ruiz \& Pav.) Poepp. \& Endl. J Ethnopharmacol 157: 149155.

CHOKCHAISIRI R, PIMKAEW P, PIYACHATURAWAT P, CHALERMGLIN R AND SUKSAMRARN A. 2014. Cytotoxic sesquiterpenoids and diarylheptanoids from the rhizomes of Curcuma elata Roxb. Rec Nat Prod 8(1): 4650 .

DONG G, LEE SY, ZHAO H, LEE Y, JEONG JH, JEON R, LEE HJ AND RYE J. 2015. Diarylheptanoids from lesser galangal suppress human colon cancer cell growth through modulating Wnt/ $\beta$-catenin pathway. J Funct Foods 18: 47-57.

GILLI C, ORLOWSKA E, KAISER D, STEYRER J, RATHGEB A, LORBEER E, BRECKER L AND SCHINNER J. 2014. Diarylheptanoids, flavonoids and other constituents from two neotropical Renealmia species (Zingiberaceae). Biochem Syst Ecol 56: 178-184.

GÓMEZ-BETANCUR I, BENJUMEA D, PATIÑO A, JIMÉNEZ N AND OSÓRIO E. 2014. Inhibition of the toxic effects of Bothrops asper venom by pinostrobin, a flavanone isolated from Renealmia alpinia (Rottb.) MAAS. J Ethnopharmacol 155: 1609-1615.

GÓMEZ-BETANCUR I, CORTÉS N, BENJUMEA D, OSÓRIO E, LEÓN F AND CUTLER SJ. 2015. Antinociceptive activity of extracts and secondary 
metabolites from wild growing and micropropagated plants of Renealmia alpinia. J Ethnopharmacol 165: 191197.

GÓMEZ-BETANCUR I, PEREAÑEZ JA, PATIÑO A AND BENJUMEA D. 2016. Inhibitory effect of pinostrobin from Renealmia alpinia, on the enzymatic and biological activities of a PLA . Int J Biol Macromol 89: 35-42.

GU J, VIGO JS, GRAHAM JG, FONG HHS, PEZZUTO JM AND KINGHORN AD. 2002. Activity-guided isolation of constituents of Renealmia nicolaioides with the potential to induce the phase II enzyme quinone reductase. J Nat Prod 65: 1616-1620.

JIRÁSEK P, AMSLINGER S AND HEILMANN J. 2014. Synthesis of natural and non-natural curcuminoids and their neuroprotective activity against glutamate-induced oxidative stress in HT-22 cells. J Nat Prod 77(10): 22062217.

KAPLAN MAC, PUGIALLI HRL, LOPES D AND GOTTLIEB HE. 2000. The stereochemistry of ledol from Renealmia chrysotrycha: an NMR study. Phytochemistry 55: 749-753.

LI J, ZHAO F, LI MZ, CHEN LX AND QIU F. 2010. Diarylheptanoids from the rhizomes of Curcuma kwangsiensis. J Nat Prod 73: 1667-1671.

LIMA HRP AND KAPLAN MAC. 2010. Quimiossistemática micromolecular e tendências evolutivas da superordem Zingiberiflorae (sensu Dahlgren). In: Kaplan MAC et al. (Eds), Abordagem Quimiossistemática e evolução química das fanerógamas. Rio de Janeiro, Editora da UFRRJ, p. 231-260

LOGNAY G, MARLIER M, SEVERIN M, HAUBRUGE E, GIBON V AND TREVEJO E. 1991. On the characterization of some terpenes from Renealmia alpinia Rott. (Maas) oleoresin. Flavour Fragr J 6: 87-91.

LUZ AIR, ZOGHBI MGB, RAMOS LS, MAIA JGS AND SILVA ML. 1984. Essential oils of some Amazonian Zingiberaceae. Br Reports 47: 907-908.

MAAS PJM. 1977. Renealmia (Zingiberaceae Zingiberoideae), Costoideae (Zingiberaceae). Flora Neotropica, New York, The New York Botanical Garden.

MAAS PJM AND MAAS H. 2015. Zingiberaceae in Lista de Espécies da Flora do Brasil. Jardim Botânico do Rio de Janeiro.

MAIA JGS, ANDRADE EHA, CARREIRA LMM AND SILVA MHL. 2007. Essential oil composition of Renealmia alpinia (Rottb.) Maas. J Essent Oil Bear Plants 10: 10-14.

MATSUMOTO T, NAKAMURA S, FUJIMOTO K, OHTA T, OGAWA K, YOSHIKAWA M, ONISHI E, FUKAYA M AND MATSUDA H. 2015. Structure of diarylheptanoids with antiallergic activity from the rhizomes of Curcuma comosa. J Nat Med 69: 142-147.
MATSUMOTO T, NAKAMURA S, NAKASHIMA S, YOSHIKAWA M, FUJIMOTO K, OHTA T, MORITA A, YASUI R, KASHIWAZAKI E AND MATSUDA H. 2013. Diarylheptanoids with inhibitory effects on melanogenesis from the rhizomes of Curcuma comosain B16 melanoma cells. Bioorganic Med Chem Lett 23: 5178-5181.

NEGRELLE RRB. 2015. Renealmia L.f.: aspectos botânicos, ecológicos, farmacológicos e agronômicos. Rev Bras P1 Med 17(2): 274-290.

NORIEGA PF, PAREDES EA, MOSQUEIRA TD, DIAZ EE, LUECKHOFF A, BASANTES JE AND TRUJILLO AL. 2016. Chemical composition antimicrobial and free radical scavenging activity of essential oil from leaves of Renealmia thyrsoidea (Ruiz Pav.) Poepp. Endl. J Med Plants Res 10: 553-558.

RAMIANDRASOA F, CHUILON S, MORETTI C AND KUNESCH G. 1986. Labda 8(17),12-diene-15,16-dial, a constituent of Renealmia guianensis (Zingiberaceae). Plant. Med Phytother 20(3): 227-230.

RASHED K, SAHUCB M, DELOISON G, CALLANDB N, BRODIN P, ROUILLÉ Y AND SÉRON K. 2014. Potent antiviral activity of Solanum rantonnetii and the isolated compounds against hepatitis $\mathrm{C}$ virus in vitro. $\mathrm{J}$ Funct Foods II: 185-191.

SEKIGUCHI M, SHIGEMORI H, OHSAKI A AND KOBAYASHI J. 2001. Pacovatinins A-C, new labdane diterpenoids from the seeds of Renealmia exaltata. J Nat Prod 64: 1102-1106.

SEKIGUCHI M, SHIGEMORI H, OHSAKI A AND KOBAYASHI J. 2002. Renealtins A and B, new diarylheptanoids with a tetrahydrofuran ring from the seeds of Renealmia exaltata. J Nat Prod 65: 375-376.

SLADE D, FERREIRA D AND MARAIS JPJ. 2005. Circular dichroism, a powerful tool for the assessment of absolute configuration of flavonoids. Phytochemistry 66: 2177 2215.

WEI Q, MA J, CAI Y, YANG L AND LIU Z. 2005. Cytotoxic and apoptotic activities of diarylheptanoids and gingerolrelated compounds from the rhizome of Chinese ginger. J Ethnopharmacol 102(2): 177-184.

YANG S, ZHOU B, MALONE S, WERKHOVEN MCM, TROON F, WISE JH AND KINGSTON DGI. 1999. A new labdane diterpenoid from Renealmia alpinia collected in the Suriname Rainforest. J Nat Prod 62: 1173-1174.

ZHOU B, BAJ NJ, GLASS TE, MALONE S, WERKHOVEN MCM, TROON F, DAVID, WISSE JH AND KINGSTON DGI. 1997. Bioactive labdane diterpenoids from Renealmia alpinia collected in the Suriname Rainforest. J Nat Prod 60: 1287-1293. 